\title{
Pojiale: Another side of the Buginese
}

\author{
Yahya Kadir \\ Department of Anthropology, Faculty of Social and Political Sciences, Hasanuddin University, \\ Indonesia.
}

Correspondence author: yahyakadir31@gmail.com

\begin{tabular}{|c|c|}
\hline ARTICLE INFO & ABSTRACT \\
\hline $\begin{array}{l}\text { Keywwords: } \\
\text { Buginese; Culture; } \\
\text { Character; Pojiale; } \\
\text { Ethnographic notes. } \\
\text { How to cite: } \\
\text { Kadir, Y. (2021). Pojiale: } \\
\text { Another side of the ethnic } \\
\text { Buginese. ETNOSIA: } \\
\text { Jurnal Etnografi } \\
\text { Indonesia. 6(2), } 307-316 . \\
\text { DOI: } \\
\text { 10.31947/etnosia.v6i2.19423. }\end{array}$ & $\begin{array}{l}\text { This paper discusses a unique side of the Bugis that has not received } \\
\text { attention in several literatures about the Bugis. The Buginese tends to } \\
\text { express himself excessively and aggressively. Local people label such } \\
\text { self-expression as pojiale, instead of using siri na pesse (one of the } \\
\text { Bugis ethics and cultural values) as the primary reference to describe } \\
\text { the character and behavior of the Bugis people, but rather based on the } \\
\text { experience and reflection of the author as a Bugis person who was born } \\
\text { and grew up in the life of the Buginese. From this experience and } \\
\text { reflection, the author finds the pojiale as the unique character possessed } \\
\text { by the Bugis. The gap between the ideal values of Bugis culture (Bugis } \\
\text { ethics and siri na pesse culture) are factually practiced in the social life } \\
\text { of the Bugis. }\end{array}$ \\
\hline
\end{tabular}

\section{Introduction}

The Buginese is an ethnic group inhabiting Indonesian archipelago (nusantara), from Malaya peninsula and Singapore to the western shore of Papua, from south Philippines to Kalimantan and Nusa Tenggara. However, they mostly inhabit the south-western part of Sulawesi Island. The Bugis population has increased year after year. In 2010, according to The Indonesian Central Bureau of Statistics (cited from Ananta, et al. 2015), the total population of the Buginese in Indonesia reached 6,400,000 people.

Although the population of the Bugis is relatively large and lives spread across various regions of the archipelago, the research on Bugis is only a few compared to the literature that describe the Javanese and the Malays (Pelras, 2006). Those limited literature also portrays the general culture and character of the Bugis people on their ideal side. In other words, the culture and character of the Bugis are described based on Bugis ethics and the cultural values of siri na pesse.

The Bugis ethics such as tau si pakatau (humanizing human), alempureng (honesty), assitinajang (propriety), and solidarity crystalize in cultural values of siri na pesse cultural values that hold the dignity of oneself, family, and others (siri), and empathize 
with others (pesse). This siri na pesse becomes operational within and through the pangadereng 1 , the institution that contains the system of norms and customary rules regulating the activities and social life of Bugis people. The next consequence is that the social life of the Bugis people protects and supports each other between patron and client, upholds the dignity of self and others, and be loyal to friends. In addition, the Buginese place the principles of honesty (alempureng) and appropriateness (assitinajang) as the orientation of their actions.

One side of the Buginese life that is unique and prominent which is not presented in any study among Bugis people is the typology of culture and characters that tend to be megalomaniac. We can see this character from the tendency of Bugis people to use a "magnifying glass" to portray themselves. They will look their self-image bigger than their real self. The enlarged self-image is then expressed in the social actions of those who tend to show off their wealth, position, academic degrees, and other ascribed titles. Their orientation is to get appreciation or to be recognized by their social environment. The Buginese label such social acts as pojiale, the character that I will discuss in this article.

\section{Culture and personality: Anthropological perspective}

Descriptions of the culture and character of the Bugis people are presented in various literatures, especially those written by the Buginese including Mattulada (1974), Rahman Rahim (1985), Muhammad Rusli (2019), Mashadi Said (2016), Kapojos et al, (2018), Zainal and Sri Wahyuni (2018), and Muhammad Huzain et al, (2021) are based on the ideal-normative framework. Such a description is a logical consequence of their theoretical foundation on culture. For them, culture is defined as sui generis and given; exists before individuals are born; and the values contained are always seen in their ideal aspects. Moreover, the ideal values of culture will have a linear influence on the character formation and behavior of individuals who are stakeholders of the culture concerned (see Benedict, in Danandjaja 1988). The implication of such a theoretical foundation is that they use the manuscripts of sureq La Galigo and Lontara as the main data sources to find the world view and cultural values of the Bugis people. Individuals who are considered as the main agents in the process of inheriting cultural values (socialization and enculturation) are parents, religious leaders, and traditional leaders.

Therefore, writings about the Buginese that are complemented by field research using an ethnographic or qualitative approach, always use cultural consultants or informants who have broad and in-depth knowledge of the ideal values of Bugis culture as data sources. The questions posed to the informants are always in an ideal-normative framework. Thus, if they find a Bugis character or behavior that is contrary to the ideal values of Bugis culture, they view it as a deviant character or behavior, and because of that, they are ignored. The consequence is that their research findings are always in line

\footnotetext{
1 According to Mattulada (1974) pangadereng includes five aspects, namely: 1) Ade is a code of conduct that serves as a guide to behavior and binds all members of the community; 2) Bicara is concerned with judicial rules that determine what is right (and fair) and what is wrong; 3) Wari is a rule regarding kinship and genealogy; 4) Rapang is concerned with past events or events that can be used as a reference for present needs; and 5) Syara is an Islamic rule or law.
} 
with the ideals of Bugis culture as presented in the manuscripts of sureq La Galigo and Lontara.

Models looking at the relationship between culture and personality have developed in anthropology since the 1920s (see Danandjaja 1988; Kodiran 2004). One of the famous figures is Ruth F. Benedict - student of the father of American Anthropology, Frans Boas. Benedict claims that within a single cultural unit, there is a possibility to develop diverse characters or temperament types because of genetic differences and the constitution (body) of each individual. However, culture only allows a limited number of these characters to develop. Those that only fit the dominant configuration. Because personality is elastic and formable, and the majority of people can adapt their personality to the configuration of the dominant culture, the majority of people in every society have a character or temperament type that is in accordance with the dominant type of society (Benedict in Danandjaja, 1988). This type of character is called a normal character or personality. Certain individuals that fail to match their character with the dominant character are referred to as deviants (Benedict in Danandjaja, 1988).

However, does the framework of thinking that puts the ideal values of culture that is sui generis and given effective in explaining socio-cultural phenomena that continue to move very quickly while the direction is often very far from ideal values? The answer is no. At the same time, this paper views culture as something that is alive and continues to move as time goes by. In other words, culture is not understood as merely forming individuals, but individuals are also seen as agents who actively shape and give content to their culture (see Ortner 1984; Abu-Lughod 1991). Moreover, value construction is no longer only carried out by the family or by religious and traditional leaders, but also by the government through educational institutions and markets promoted by the mass media. As a result, besides the culture being very dynamic, market ideology has also helped shape the character of individuals in society.

Due to that perspective, this paper does not use the La Galigo and Lontara manuscripts as the main references, but rather refers to the author's deposition of experience as an "insider" - born, raised, and interacted with the Bugis people - and at the same time as an "outsider" - interacting with various "outside" cultures and engaging with contemporary thoughts in the field of anthropology.

As an "insider", the author is exposed to various styles of Bugis life. Therefore, the meaning and orientation of their social actions are recorded and embedded quite deeply in the writer's map of consciousness. Furthermore, as an "outsider", the author can distance himself and reflect on the social actions of the Bugis. Through this reflection, in addition to finding the unique character possessed by the Bugis (pojiale in this article), it also appears that there is a very wide gap between the ideal values of Bugis culture as stated in the La Galigo and Lontara manuscripts, and the factual conditions of Bugis social life, especially in this contemporary era. Methodologically, this kind of ethnographic research is known as autoethnography (see Reed-Danahay 2021). 


\section{Pojiale: Natural character or cultural construction?}

Is the character of pojiale an embodiment of the basic human needs to get recognition (appreciated and recognized for his achievements and reputation) from his social environment; or is it more of a cultural construct? Before answering this question, we will first discuss Maslow's hierarchy of needs theory.

A psychologist, Abraham Maslow, in his book A Theory of Human Motivation (1943) suggests that humans have five basic hierarchical needs: physiological needs, safety/security needs, social needs, esteem needs, and self-actualization needs. Appreciation of needs starts from physiological needs, and if they are minimally fulfilled, then the next need is realized, namely the need for security to the fulfillment of self-actualization needs (Maslow and Witarto, 2010).

Maslow further states that the satisfaction of these needs is driven by two forces: deficiency motivation and growth motivation. The purpose of deficiency motivation is to overcome various deficiency problems experienced by humans. Meanwhile, the motivation for growth is based on the capacity of each person to grow and develop. This capacity is innate to everyone.

Physiological need is the most basic need for physical survival and is a prerequisite for all other needs. Things that include physiological needs are food, drink, shelter, sleep and oxygen. Hungry humans will always be motivated to satisfy their hunger by looking for and eating food, and not motivated to find friends and be rewarded. Humans will suppress all other needs before their physiological needs are minimally met. Humans whose level of socio-economic life has been established, in choosing the food to be consumed is no longer just to satisfy their hunger but has thought about the taste, texture and the place where the food is served. Meanwhile, for humans who are hungry, the main motivation is to be full or satisfy their hunger.

There are two things that distinguish physiological needs from other needs. First, physiological needs are the only needs that can be completely satisfied. If a person is full, he no longer has the desire to eat. Second, the nature of repetition. After humans eat, they will eventually become hungry again and will continue to search for food. Meanwhile, higher-level needs do not appear continuously. For example, a person who has their need to be loved and appreciated is satisfied will still feel confident that they can maintain the fulfillment of that need without having to look for it again.

After the physiological needs are satisfied minimally, the need for security will emerge from various physical and psychological threats. Humans seek and expect protection from physical security threats, such as: war, crime, terrorism, riots, natural disasters, and disease. Humans also have a need to be free from various things that threaten mental conditions, such as being harassed, looked down upon, humiliated and stressed. The need for security differs from physiological needs since this need cannot be completely satisfied. Humans cannot be fully protected from the threat of disease, natural disasters, and barbaric actions from other people.

The need for belongingness and affection arises when physiological and safety needs are met at a minimal level. People will look for friends, partners, offspring, harmonious 
relationships with nuclear and extended families. A person who has received affection since childhood will not panic when a certain individual refuses to be friends with them or if their love is rejected. They have great confidence that there will be someone else who is really important to them who will accept the feeling.

After the needs for love and belonging are fulfilled, humans will try to fulfill their ego needs to achieve and have prestige. Maslow classified two categories of esteem needs, namely lower and higher needs. Low needs are the need to get respect from others, the need for status, fame, glory, reputation, and power/domination. The high need is the need for self-esteem including feelings, beliefs, competence, achievement, mastery, independence, and freedom. Once humans can satisfy the esteem needs, they are ready to enter the gate of self-actualization, the highest need.

The need for self-actualization is the last level of basic human needs. At this stage, a person will try to develop as much as possible all the potential they have. In other words, everyone has a strong desire to realize all the abilities they have. Initially, Maslow assumes that self-actualization needs will arise automatically when the needs for belongingness and affection are met. However, he later changed and repudiated the claim after seeing a number of young people who were successful and fulfilled lower needs, and had not been able to achieve self-actualization.

By referring to Maslow's theory, then is the pojiale character a manifestation of social needs and the need for self-esteem for the Bugis people? The answer depends on the perspective we use. If the point of view that we use follows the perspective of the Bugis, then the answer is to fulfill the need for self-esteem. For the Buginese, showing off their wealth, position, academic degrees, and other traditional titles make them feel that their social relations will be built. They also fell being rewarded that their reputation and achievements are recognized by their social environment. However, if we use Maslow's perspective, the author believes that the pojiale character is not a manifestation of efforts to fulfill social needs and self-esteem needs. This is because their fulfillment does not follow the hierarchy of basic human needs, but the spirit is more self-inflating in order to get recognition and appreciation from their social environment.

Thus, the pojiale phenomenon is more of a cultural construction than a manifestation of the basic human drive to fulfill the need for esteem as a logical consequence of the fulfillment of physiological needs, safety, and social needs. This pojiale seems to be in line with one of the types of kwakiutle culture that Benedict describes as megalomania seeing himself as a great person.

\section{Marriage as an arena for Pojiale's expression}

The wedding ceremony -the entire procedure that occurs in the process of organizing and celebrating a wedding from the application to the official banquet- is the arena used by the Bugis to demonstrate their control over economic resources, social position, status, and reputation. The wedding ceremony also serves to affirm social status and increase social position or social climbing. Therefore, the sponsor or organizer of the wedding ceremony will exert as much as possible all the economic energy he has to finance the wedding party. One part of the Bugis wedding procession is the groom's 
hand over the shopping money (doi menre') to the bride's parents. The nominal amount of doi menre' is closely related to the socioeconomic status of the party conducting the marriage ceremony. The higher the social status of the bride, the higher the doi menre' that must be submitted by the groom to the bride. The amount of doi menre' is also a reflection of the achievement status of the groom.

Because spending money is a marker of social status, although the amount of spending money handed over by the groom to the bride is not announced, it is easily known by the community, also if the nominal value of spending money is very large. For example, there is a case in which the spending money handed over by the groom's family who applied for the son of a wealthy businessman's family in Soppeng Regency was Rp. $3,000,000,000$, - (three billion rupiah). The shopping money received by the women is used to fund the wedding party. It is also common to find cases in which the bride's family spends more than the money they receive, so they need additional funds to cover it. Additional funds were obtained through the number of invitations distributed and attended people of the wedding reception along with the total contents of the invitation envelope. Usually, the size of the envelope is smaller than the additional funds used to finance the wedding party. The groom's side spends twice as much as the bride's side. In addition to spending money that is handed over to the bride's family, it is also for the costs of her own wedding party.

Other things that become markers of the social status of the party implementing the wedding are the quality of the invitations, who invited (name, title, and position), the number of invitations distributed and who was invited and who was present at the wedding reception, and where the wedding reception was held. Thus, spending money, the quality of the invitation, and the excitement of the wedding party are markers of social status that are extravagant, show off, and are aggressive (see Millar, 2009).

In addition, during the wedding ceremony, the guests present will use and show off the most expensive accessories they have. Gold necklaces that were sometimes the size of a little finger hung from the outside of the garment; on his arms lined gold bracelets; the clothes used are often equipped with gold safety pins; and even in certain areas rich women complete their accessories by using gold braid straps.

The pojiale character is also expressed in religious symbols. For example, many Bugis people who are known as staunch adherents of Islam will and have performed the pilgrimage (hajj or haji), but some of them whose main motive is not because of a call to faith, but because they expect appreciation and respect from their social environment. In that context, it is understandable if there are several families whose economic level is classified as prosperous - especially prior to the limitation of quotas for pilgrims bringing their unmarried children to the holy land to perform the pilgrimage (hajj). In terms of Islamic law, it is not obligatory to perform the pilgrimage. Bugis people refer to children who have performed the pilgrimage as Haji lolo (for men) or Haja lolo (for women), means the Young Hajj. After all, those who carry the title as Haja lolo are generally girls. Why girls? One of the reasons is related to the amount of spending money (doi menre') which will be submitted by the man who will later ask for her hand as a wife. Apart from that, it is also understandable why the number of registrants for 
Hajj pilgrims is very large from the Province of South Sulawesi. It is one of the largest numbers outside of the provinces of Java. ${ }^{2}$

\section{Potlatch and Bugis marriage: A comparison}

Potlatch is one of the most studied cultural practices by anthropologists. Potlatch is a very lively event in the regional exchange system among the tribes of the North Pacific Coast of North America. During the event, individuals or families who are sponsors of the event assisted by members of their community distribute food, blankets, pieces of copper, and other valuables. In return, they get prestige and recognized reputation.

The potlatch event not only contradicts classical economic theory which assumes that the profit motive is universal, with the aim of maximizing material profits, but also contradicts the Protestant ethic which requires its followers to work hard and be economical (see Weber, 2015). Economist Thorstein Veblen in his book The Theory of the Leisure Class (1934) quoted by Kottak (2015) reveals that potlatch events are based on an irrational economic drive for prestige. Their material welfare is sacrificed to maximize prestige.

The interpretation of potlatch as an act of waste was rejected by ecological anthropologists, Wayne Suttles (1960) and Andrew Vayda (1961/1968). They view potlatch not in terms of its waste, but its long-term role as a cultural adaptation mechanism. How does it work? The characteristics of the natural environment throughout the North Pacific Coast region are favorable, but resource availability fluctuates from year to year and from place to place. This means that the availability of salmon and herring in abundance is not the same every year for each location. One village can have a good year while another village can have a bad year. On the other hand, villages that previously had a good year may have a bad year, and villages that previously had a bad year later will have a good year. In that context, the potlatch cycle is not a competitive display that does not bring material advantages.

Villages that experience a favorable year will experience a surplus of subsistence goods that can be exchanged for more durable goods of wealth, such as blankets, canoes, or scraps of copper. Meanwhile, other regions are experiencing a less favorable situation. Wealth held by villagers living in auspicious years is in turn distributed and converted into prestige through potlatch. Residents of several villages are invited to potlatch and take home the given resources. In this way, it links villages that are intertwined in a regional economy - a system of exchange that distributes food and wealth from the rich to the needy. In return, their potlatch and village sponsors gain prestige. The decision to potlatch is determined by the state of the local economy, meaning that the potlatch is held in the fortunate year, when there is a surplus in the resources.

The long-term adaptive value of inter-community parties becomes clear when we consider what happens when a once prosperous village suffers bad luck. Its inhabitants began to accept invitations to attend potlatches in villages where conditions were better. Food and wealth were distributed to villagers in need. Becoming the receiver of the food

2 See https://www.bps.go.id/indicator/27/178/1/jumlah-jemaah-haji-yang-diberangkatkan-ke-tanahsuci-mekah-menurut-provinsi.html 
and wealth means releasing some of their prestige. They are willing to receive rather than give gifts and thus relinquish some of their stored prestige. They hoped that luck would eventually improve, so that resources could be reclaimed and prestige back.

Potlatch connects local groups along the North Pacific Coast into regional alliances and exchange networks. Potlatch and exchange between villages has an adaptive function, regardless of the motivation of each participant. Anthropologists who emphasize competition for prestige are not wrong. They only emphasize the motivation behind potlatch events and ignore the analysis of economic and ecological systems.

In addition, the practice of potlatch can prevent the development of socio-economic stratification, the social class system as in the capitalist economic system. Wealth is released and converted into immaterial goods (prestige). Capitalism requires people to invest their profits in the hope of making additional profits so that their wealth will increase. However, the tribes who practice potlatch are happy to give up their excess or wealth rather than using it to widen the social distance between themselves and their fellow tribesmen.

From the description above, it appears that the pojiale which is exhibited at a Bugis wedding party to gain prestige has similarities with potlatch. However, it is different in terms of its adaptation role, where the potlatch event plays a role in overcoming the fluctuating situation of resource availability experienced by villages on the North Pacific Coast. With potlatch, villages that are experiencing famine situations are overcome by having potlatch parties. In addition, potlatch prevents the infiltration of capitalism which widens social distance between them and their fellow tribesmen. Meanwhile, pojiale which is demonstrated through a wedding party does not seem to play a role in preventing the infiltration of capitalism and social distance. In fact, it is in line with the spirit of capitalism and the wedding party is a place to maintain and increase social position.

\section{Conclusion}

The character of the Bugis as the writer observes, experiences, and feels is far from the ideal values of Bugis culture. Social relations which in Buginese ethics are based on the ati macinnong (clear conscience), and from this will be born good faith, honesty, appropriateness, and solidarity; but the fact is diametrically different from what is practiced in the social life of the Bugis.

The existence of a distance between the ideal values of Bugis culture and those that are factually practiced in daily interactions raises several questions: Does the ideal values of Bugis culture that later shape the character of the Bugis people as contained in the manuscripts of sure La Galigo and Lontara ever present factually in the life of the Bugis? Or is it just the hope of the Bugis philosophers in the past? If it has really been actualized in the life of the Bugis, then the question is what are the factors that cause the ideal values and the noble character of the Bugis to lose?

Apart from the distance between the ideal values of Bugis culture and those practiced by the Bugis, the pojiale character is the main driving factor that drives the wheels of Bugis life. In fact, it may even be the pojiale character that makes Bugis people as great 
seafarers, having the ability to adapt to their new environment, but their Bugis identity is maintained.

Conflicts of Interest:

The author declares that there is no conflict of interest.

Acknowledgement:

This article is an auto-ethnographic record of Bugis culture that I reflect on daily experience. Although this article does not intend to generalize Bugis culture, at the same time, the practice of Pujiale can be found in various other ethnic groups in Indonesia.

\section{References}

Ananta, A., Arifin, E. N., \& Bakhtiar. (2005). Ethnicity and ageing in Indonesia, 20002050. Asian Population Studies, 1(2), 227-243.

Pelras, C., Abu, A. R., \& Arsuka, N. A. (2006). Manusia Bugis. Nalar: Forum JakartaParis: École Française d'Extrême-Orient (EFEO).

Bakti, A. F. (2010). Diaspora Bugis di Alam Melayu Nusantara. Makassar: Ininnawa.

Bateson, G., \& Mead, M. (1942). Balinese character: A photographic analysis. New York, 17-92.

Benedict, R. (1974). Ruth Benedict. Columbia University Press.

Danandjaja, J. (1988). Antropologi psikologi: teori, metode dan sejarah perkembangannya.

Goodenough, W.H. (1994). “Toward a Working Theory of Culture” in Robert Borofsky (ed.) Assessing Cultural Anthropology. New York: McGraw-Hill Inc, pp. 262-275.

Huzain, M., Rajab, H., \& Wekke, I. S. (2016). Sipakatau: Konsepsi Etika Masyarakat Bugis. Deepublish.

Kapojos, S. M., \& Wijaya, H. (2018). Mengenal Budaya Suku Bugis. Jurnal Lembaga STAKN Kupang | MATHETEUO Vol, 6(2), 153.

Keesing, R. M. (1992). Cultural Anthropology: A Contemporary Perspective; Antropologi Budaya: Suatu Perspektif Kontemporer, Terj. RG Soekadijo, Edisi kedua, Jakarta: Erlangga.

Kodiran. (2004). Pewarisan Budaya dan Kepribadian (Cultural Inheritance and Personality). Jurnal Humaniora, Volume 16 No. 1.

Kottak, C. P. (2015). Cultural anthropology: Appreciating cultural diversity. McGraw-Hill Education.

Mattulada, H.A. (1974). Bugis-Makassar: Manusia dan Kebudayaannya. Berita Antropologi, Jakarta (edisi khusus).

Mattulada, H. A. (1995). Latoa suatu Lukisan Analis terhadap Antropologi Politik Orang Bugis, penerbit Gadjah Mada University Press.

Millar, S. B. (2010). Perkahwinan Bugis, Refleksi Status Sosial Dan Budaya Di Baliknya. Penerbit Ininnawa.

Moein MG, A. (1977). Menggali Nilai Sejarah Kebudayaan Sulselra Siri' \& Pacce. Ujung Pandang: SKU Makassar Press.

Noorduyn, J., \& Salim, M. (1988). Special Buginese characters in Luwu'manuscripts. Bijdragen tot de Taal-, Land-en Volkenkunde, 144(2/3), 351.

Ortner, S. B. (1984). Theory in Anthropology since the Sixties. Comparative studies in society and history, 26(1), 126-166.

Christian, P. (2005). Manusia Bugis. Jakarta: Nalar.

Rahim, A. R. (1985). Nilai-Nilai Utama Kebudayaan Bugis. Ujung Pandang: Lembaga Penerbitan Universitas Hasanudin. 
Reed-Danahay, D. E. (2021). Leaving home: Schooling stories and the ethnography of autoethnography in rural France. In auto/ethnography (pp. 123-143). Routledge.

Rusli, M. (2019). Impelementasi nilai Siri'Napacce dan agama di tanah rantau; Potret Suku Bugis-Makassar Di Kota Gorontalo. AL ASAS, 3(2), 73-86.

Said, M. (2016). Jati Diri Manusia Bugis. Jakarta: Pro De Leader.

Abidin, A. Z. (1999). Capita Selecta Kebudayaan Sulawesi Selatan.

Zainal, Z., \& Wahyuni, S. (2018). Siri'Na Pesse dalam Masyarakat Bugis di Kota Tanjungpinang. Jurnal Masyarakat Maritim, 2(1), 34-44.

Saudagar Bugis-Makassar - "Pertemuan Saudagar Bugis-Makassar: Janganlah Melupakan Budaya" (Bugis-Makassar Merchants - "Bugis-Makassar Merchant Meeting: Don't Forget Culture), Kompas, Diakses 15 Desember 2021.

Weber, M. (2015). Etika Protestan dan Semangat Kapitalisme. Yogyakarta: Narasi.

Wijono, S. (2010). Psikologi industri \& organisasi. Kencana. 